\title{
Public Service Broadcasting as an Object for Cultural Policy in Norway and Sweden A Policy Tool and an End in Itself
}

\author{
Håkon Larsen
}

\begin{abstract}
The future of public service broadcasting (PSB), and its role for democracy and culture in an age of globalization and digitalization, is a disputed issue among communication scholars, journalists, the general public and politicians. The PSB institutions are dependent on political support for their survival, and they have to live up to cultural policy obligations. The focus of this analysis is on the rhetoric employed in the white papers on PSB and overall cultural policy, produced between 2005 and 2007 in Norway and Sweden. The analysis shows that both countries emphasize the need to secure an inclusive public sphere, a vivid democracy and a national culture. The rhetoric differs in the sense that the Norwegian focus is on PSB as a tool for achieving cultural policy goals, while the Swedish focus is more on why the idea of PSB is important in itself.
\end{abstract}

Keywords: public service broadcasting, cultural policy, media policy, cultural repertoire, Norway, Sweden

\section{Introduction}

Public service broadcasters have traditionally been strong media institutions in Scandinavia. Today, the institutions are struggling to maintain their centrality and importance, as a result of the ongoing technological and economical development within the media landscape. The future of public service broadcasting (PSB) is a debated issue among scholars, politicians, journalists and the general public - "The new context of PSB has serious consequences for every aspect of its operations: for its mission, programming, organization and funding" (Bardoel and l'Haenens 2008: 342). Being publicly funded institutions, public service broadcasters have to fulfill cultural policy obligations (in both Norway and Sweden it is the Ministry of Culture that is responsible for policies related to PSB). It is these policy obligations, and how they are portrayed rhetorically, that are the focus of this article. I will conduct an analysis of cultural policy discourses on PSB in Norway and Sweden, focusing on the white papers on PSB produced between 2005 and 2007, and the white papers on overall cultural policy, preceding the papers on PSB. I do this because "the media policy is an important part of the cultural policy" (St. meld.nr. 30 (2006-2007): 8). There is a tradition within media studies of studying media 
from a cultural policy perspective (usually focusing on the public sphere) (Syvertsen 2004: 17-22), ${ }^{1}$ but few of these investigations incorporate other areas of cultural policy in their analysis (one exception being Hesmondhalgh 2005). I study both policy related to PSB and overall cultural policy - policy guiding the more specific sectors for which the Ministry of Culture is responsible. Because this overall cultural policy covers all the areas of culture and media that are the Ministry's responsibility, it is of a principled nature, focusing more on values than on practical politics. The document study will be supported and contextualized with references to results from a questionnaire that I have distributed among the cultural spokesmen for political parties in the two countries, and with in-depth interviews that I have conducted with leaders of the PSB organizations Norsk rikskringkasting (NRK) and Sveriges Television (SVT).

The main research questions can be formulated as follows: How is PSB related to democracy and culture, and how is the changing media landscape handled rhetorically by cultural politicians in Norway and Sweden? I will start by giving a short introduction to the tradition of PSB in general and in Scandinavia in particular. The data analyzed and the main analytical concepts of the study will then be presented, before I turn to the analysis of the rhetoric related to cultural policy and PSB in the two countries.

\section{PSB in Scandinavia}

PSB, in its classical form, refers to broadcasting with a mission to "inform, educate and entertain", an idea that was given its institutional form, as an institution independent of both political and economic interests, by the first CEO of the BBC, John Reith (1924). In Norway and Sweden, the public service broadcasters receive most of their funding through a license fee, paid by citizens who own a TV set. ${ }^{2}$ Promoting national culture and serving democracy are key features of the PSB mission. And it is this mission - as it is approached from a cultural policy perspective - that I will analyze.

In Scandinavia, the PSB institutions played an important role in the social democratic project of the $20^{\text {th }}$ century. They were delegated responsibility for enlightening the people, motivated by the egalitarian and social democratic ideals of providing information to the public and enabling citizens to act as critical and independent subjects (in a Habermasian ideal of the public sphere (Habermas 1989)). Although this might seem as an elitist and paternalistic idea (from afar), it is motivated by the ideal of equal access for everyone, and is thus in line with social democratic values. "The central idea of popular education (enlightenment [of the people]) is to promote equality and to reduce the knowledge gap. It is about redistributing the cultural capital" (Bengtsson 2002: 86) [translation by author].

Scandinavia stands out as a region of Europe (and the world) with many common features, regarding the social democratic welfare state (Esping-Andersen 1990; Sejersted 2005) and the structure of the media system (Hallin and Mancini 2004). On this foundation, it is interesting to make a comparison between countries in the region, based on a "most similar systems design", where one considers "[...] systems as similar as possible with respect to as many features as possible [to] constitute the optimal samples for comparative inquiry" (Przeworski \& Teune 1970: 32). The choice to compare Norway and Sweden (and leave Denmark out) is motivated by the fact that these two countries share even more with each other than they do with Denmark (Sejersted 2005: 16; Gundelach 2000). ${ }^{3}$ 
In Norway, NRK is the only public service broadcaster, delivering content on television, radio, Internet and mobile phones, whereas in Sweden there are three such PSBs: SVT, Sveriges Radio (SR) and Utbildningsradion [Swedish Educational Broadcasting Company] (UR). NRK is a limited company where the state owns all the shares and appoints the chairman of the company, which again appoints the CEO. In Sweden, on the other hand, the PSB companies are owned by a foundation. It can then be argued that the Norwegian broadcaster has a closer relationship to the government than do the Swedish broadcasters, but then again the members of the board of the foundation are appointed by the Swedish government. However, all the organizations have editorial freedom, which can be related to the principle that the institutions should maintain an arm's length distance to the government - a principle that is fundamental to the idea of PSB.

\section{Policy Documents}

The white papers analyzed here are called Stortingsmelding (short: St.meld.) in Norway and Regeringsproposition (short: Prop.) in Sweden (all the citations from these papers have been translated into English by the author). The main papers under analysis are: St.meld.nr. 30 (2006-2007) Kringkasting $i$ en digital fremtid [PSB in a Digital Future] and Prop. 2005/06:112 Viktigare än någonsin! Radio och TV i allmänhetens tjänst 2007-2012 [More Important Than Ever Before! Radio and TV in the Public's Service 2007-2012].

A Stortingsmelding is used when the government wants to present issues for the Storting [national parliament] without it being tied to the proposition of laws or plenary decisions. Stortingsmelding is usually a report to the Storting about the work that is being done on a particular field, or a consideration of future policy. The stortingsmelding, and its processing in the Storting, often make up the basis for a future bill. ${ }^{4}$

In Sweden, there is no publication that corresponds directly to a St.meld. The Swedish Prop. serves the purpose of presenting a bill to the Riksdag [national parliament], but the bill is often accompanied by a more general orientation to a policy field. The propositions analyzed in the present study are all broad orientations. Prop. 2005/06:112 is about general guidelines and objectives for the licensing period to come for the Swedish PSBs as well as a proposed change in the law on TV and Radio. Both St.meld. and Prop. have the Government as the addresser and serve the purpose of communicating the Government's official viewpoint on the matters at hand to the national parliament. A prop. usually contains a presentation of aspects that have been discussed in a preceding report by an advisory committee to the government (a SOU; "Statens offentliga utredningar"), as well as comments on the report given by consultative bodies ("remissvar"). A St.meld., on the other hand, does not always have a preceding report by an advisory committee (a NOU; "Norges offentlige utredninger") or comments from consultative bodies ("høringsuttalelser"). ${ }^{5}$

The St.meld. that makes up the main part of the data for this article - St.meld.nr. 30 (2006-2007) - presents a proposal before the parliament before receiving comments from consultative bodies. St.meld.nr. 6 (2007-2008) about the NRK decree - which "[...] should on a general level express the community's expectations and demands to NRK" (St.meld.nr. 6 (2007-2008): 5) - on the other hand, serves the purpose of present- 
ing the response from consultative bodies (the main Norwegian paper on PSB, St.meld. nr. 30 (2006-2007), is accompanied by two minor supplementary papers: St.meld.nr. 6 (2007-2008) and St.meld.nr. 6 (2008-2009)). The preceding papers on PSB (St.meld. nr. 57 (2001); Prop. 2000/01:94) and overall cultural policy (St.meld. nr. 48 (2002-2003); Prop. 1996/1997: 3) ${ }^{6}$ will also be drawn upon in the analysis.

As I mentioned in the introduction, I will also present some results from a questionnaire on culture policy and PSB completed by one representative from each of the eight largest political parties in the two countries, all members of the committees dealing with cultural policy in the national parliaments or otherwise involved with the cultural policy of their respective parties at the time of completion of the questionnaire (October 2007-March 2008). A third data set includes interviews with program directors, managers and executives in the PSB institutions NRK (four interviews) and SVT (five interviews). I will draw on these to relate the findings from the policy study to the institutional reflexivity of the broadcasting institutions.

\section{Analytical Concepts}

An important term in this study is rhetoric, which is employed in its classic definition dating back to Aristotle (1925), where it concerns persuading others of one's standpoint using the means one has at hand. Another central term is national cultural repertoires (Lamont and Thévenot 2000; also Lamont 1992: 136-139), inspired by repertoire theory (Swidler 1986: 273), which views “'[...] culture as a 'tool kit' of symbols, stories, rituals, and world-views, which people may use in varying configurations to solve different kinds of problems". The term national cultural repertoire is introduced as an alternative to traditions in comparative sociology that deal with political and institutional crossnational differences, as well as simplistic essentialist models of national character.

National cultural or historical repertoires [...] are defined as relatively stable schemas of evaluation that are used in varying proportion across national contexts. Each nation makes more readily available to its members specific sets of tools through historical and institutional channels, which means that members of different national communities are not equally likely to draw on the same cultural tools to construct and assess the world that surrounds them (Lamont and Thévenot 2000: 8-9).

The study at hand focuses on how politicians and bureaucrats portray the public service mission discursively, seen as part of the overall cultural policy. One might see a slightly different rhetoric in the two countries, as the PSB rhetoric is more or less strategically adapted to the national context and its available cultural repertoire. PSB has been adapted to many countries and the national repertoire will therefore influence the rhetoric that is used to portray the idea and the particular institution's mission in each nation. The national repertoire limits the rhetorical repertoire that can be employed within normative positions - discourses - on PSB.

\section{In Support of Democracy and the National Culture}

Let us start out by looking at what the main papers for analysis say about democracy, as democracy is a focal point in the legitimizing rhetoric of PSB (Garnham 2003; Jacka 
2003; Larsen 2008; Moe 2008). The method I have used is searching for the word "democracy" in the documents and analyzing the contexts in which they are used. I am thus analyzing how the democratic mission of PSB is explicitly articulated, as opposed to its more implicit articulations. What do the documents have in common when articulating PSBs democratic role?

To begin with, they both contain "classical" formulations on the role of PSB in democracy. ${ }^{7}$ In a presentation of the term PSB, the Norwegian paper states that the term, among other things, entails " $[\ldots]$ a mission to contribute to providing the individuals with sufficient information to take part in democratic processes, and provide programs that can be a source of insight, reflection and knowledge" (St.meld.nr. 30 (2006-2007): 45). And in the Swedish paper, there is an emphasis on democratic values in the description of the most important principles for the licensing period to come: "The PSB companies should monitor their PSB services so they serve the creation of independent attitudes and make room for a plurality of expressions of attitudes and values" (Prop. 2005/06:112: 32).

These formulations are in line with a Habermasian notion of democracy and the public sphere, with its focus on rational argumentation in a universalistic and unitary public sphere, in principle open and by nature inclusive of all fellow citizens, as a cornerstone of any liberal representative democracy (Habermas 1989; 1996). A crucial element in maintaining such a public sphere is the provision of a common set of references to the citizens. This is stressed in the policy documents. In the Norwegian paper, it is related to the creation of a national culture and identity, while the Swedish paper focuses more on common references being central to a well-functioning democracy (the same conclusion was drawn in comparing the legitimizing rhetoric of NRK and SVT (Larsen 2010)). ${ }^{8}$ The former is an important cultural policy objective for PSB, while the latter is a vital aspect of the media policy discourse, where democracy, freedom of speech and press freedom are rhetorical focal points. ${ }^{9}$ Public service broadcasters are thus considered to be important institutions for securing the continuation of both the imagined communities (Anderson 1991) of their respective countries and a public sphere that is inclusive of all, thus emphasizing the values of the ideal public sphere that Habermas (1989; 1996), Garnham (1992) and Sunstein (2007) describe. ${ }^{10 ~ "[\ldots] ~[M] ~ a n y ~ o r ~ m o s t ~ c i t i z e n s ~ s h o u l d ~ h a v e ~ a ~ r a n g e ~}$ of common experiences [...] Common experiences, emphatically including the common experiences made possible by the media, provide a form of social glue" (Sunstein 2007: 6).

The strong emphasis on the preservation and creation of a national culture and identity in Norway can be interpreted in light of the fact that the Norwegian language (and culture) is practiced by only half as many as there are speakers of the Swedish language. Moreover, Norway has two official forms of written Norwegian - Norwegian Bokmål and Norwegian Nynorsk. The latter was created in the middle of the 1800s by Ivar Aasen, based on a collection of dialects. It was introduced as an alternative to the official written language in Norway, which was heavily influenced by Danish as a consequence of Norway having been under the Danish throne for centuries, until $1814 .{ }^{11}$ A specific cultural policy objective for NRK is that 25 percent of its program offering should be in Norwegian Nynorsk. The Swedish PSB organizations are also obliged to deliver content in specific minority languages, but the objective is not as specific as that related to NRK. NRK is one of few institutions in Norway where Norwegian Nynorsk is spoken (the language is mostly practiced in writing), so the 25 percent demand is a crucial cultural policy obligation for NRK. 


\section{PSB as a Policy Tool}

The formulations of the democratic mission of the PSB institutions differ in the way the more general principles are operationalized. One difference is that the Norwegian document is closer to the formulations in the European Council's "protocol on public service broadcasting", laid down in Amsterdam in 1997, and its instrumental approach to the democratic function of the national PSB institutions of Europe: "[...] the system of public broadcasting in the Member States is directly related to the democratic, social and cultural needs of each society and to the need to preserve media pluralism" (EU 1997: 1) [italics added by author]. The expression that PSB should serve "democratic, social and cultural needs" is mentioned a total of 13 times in the three Norwegian papers (St.meld. mr. 30 (2006-2007); St.meld.nr.6 (2007-2008); St.meld.nr.6 (2008-2009)), the first point in the NRK decree being "NRK's overall public service offering should aim at meeting the democratic, social and cultural needs of society" (St.meld.nr.6 (2008-2009): 2). Also the Norwegian Law on Broadcasting (LOV-1992-12-4-127) was changed in 2009, where one of the new formulations related to NRK was: "Only services that fulfill democratic, social and cultural needs of society can be approved" (§ 6-1a). The Amsterdam protocol (EU 1997) is only referred to once in the Swedish white paper on PSB (Prop. 2005/06: 112), without the appearance of the expression "democratic, social and cultural needs" (the expression does not appear in the previous papers of either country: St.meld.nr. 57 (2000-2001) and Prop. 2000/01: 94). ${ }^{12}$

An instrumental approach to PSB is also apparent in the descriptions of digitalization in Norway (there is a stronger focus on digitalization and the changing media landscape in the Norwegian case, which may be because the Swedes digitalized their broadcast media earlier than the Norwegians $\operatorname{did},{ }^{13}$ resulting in the Swedes being finished with discussing digital television): "NRK emerges as the most important instrument in the media sphere. Digitalization entails tougher competition for the company. In such a situation of competition, one should not do anything that could weaken NRK's foundation for financing" (St.meld.nr. 30 (2006-2007): 63) [italics added by author]. The Norwegians also tend to employ a more economically inspired rhetoric than do the Swedes. Comparative studies of public debates on the role of PSB (Larsen 2008), the political debates on digital terrestrial television (Storsul \& Sundet 2006), and the institutions legitimizing rhetoric (Enli 2006; Larsen 2010) all come to such conclusions. Also, when asked about the importance of ratings for the legitimacy of PSB in the distributed questionnaire, the Norwegian cultural politicians found it to be more important than did their Swedish colleagues.

However, it is not only in the Norwegian paper that PSB is dealt with using an instrumental approach; in the Swedish paper, the PSB institutions are told to work toward the achievement of gender equality, containing formulations like - [t]he PSB companies can, by avoiding showing stereotypical representations and traditional gender roles and instead focusing on positive examples, contribute to a development towards a more gender equal society. Gender equality should be the starting point in all program production (Prop. 2005/06:112: 116).

Similar statements also appear in the preceding white paper (Prop. 2000/01:94). The gender issue is absent from the Norwegian papers on PSB (St.meld.nr. 57 (2000-2001); St.meld.nr. 30 (2006-2007); St.meld.nr.6 (2007-2008); St.meld.nr.6 (2008-2009)). The Swedish focus on gender equality can be seen in light of the high level of awareness 
of this issue in Swedish society: Being the most gender equal society in the world is very important for Swedes, and feminist issues make up a relatively large part of the public discourse, culminating in the launch of the feminist party Feministisk Initiativ [Feministic Initiative] in 2005.

\section{Enlightening the Public}

With digitalization the importance of flow ${ }^{14}$ decreases, as the audience has several options regarding when and where to consume the content produced by broadcasters. Despite this, flow is still part of the rhetoric related to PSB as an object for cultural policy in Sweden:

A varied program offering gives the audience the possibility to gain insight into other people's lives, cultures and practices, which can contribute to an enhanced understanding and tolerance that will strengthen the democracy. It is important to provide a broad program offering during prime time in TV and radio (Prop. 2005/06:112: 31-32).

Such an explicit educational approach was opposed by NRK's chairman and former Minister of Culture and Science, Hallvard Bakke, when I interviewed him on March 11 2008: "You cannot force people to watch news or debate programs. It is a matter of free will, and it should be. But these programs have high ratings, so I think NRK is very important in that area". Bakke distances himself from such an approach, but is still satisfied with the fact that people watch the informational programs. This is a good illustration of the differences between the Norwegian and the Swedish rhetoric: the values of PSB are quite similar in both countries, but when arguing for these values in Sweden one uses a more explicit rhetoric, relating it directly to the values, than is the case in Norway.

In general, the Swedish papers contain more formulations of an abstract or philosophical nature than is the case in Norway, as this extract exemplifies:

The value that PSB can create can influence people on several levels. It creates a value or utility for people as individuals, assuming that the program offering is made to address the whole public, the broad segment as well as the narrow interests. In addition, values for human beings as fellow citizens - and through that for society as a whole - are created through program activities dedicated to promoting social, cultural and democratic processes (Prop. 2005/06:112: 108).

The last part of this formulation is inspired by the Amsterdam protocol (EU 1997). But where the Norwegian paper contains formulations treating PSB like an instrument used to fulfill needs considered important for society ("serve democratic, cultural and social needs"), the Swedish statement can instead be viewed as portraying the PSB institutions as contributing to what will be considered important values in society, by "promoting social, cultural and democratic processes".

The specification of the democratic mission of the PSB institutions is more or less identical in both countries, except for the focus on gender equality in Sweden, and the higher focus on new PSB services in Norway (e.g. Internet and mobile phone services). But the rhetoric differs in that the democratic aspects of the policy discourses on PSB are being articulated in more instrumental and concrete terms in Norway and in more 
philosophical and abstract terms in Sweden (Norwegian cultural policy is often described as being instrumental from the 1980s onwards, cultural policy being viewed as an instrument used to achieve goals in other policy fields (Vestheim 1995, Røyseng 2008)). This rhetorical difference corresponds to differences in the description given by the program directors, managers and executives of NRK and SVT when interviewed on the role of PSB in the changing media environment (Larsen 2010).

There are different traditions in the two countries regarding how to write government propositions and reports, where the Swedish documents tend to be longer and contain more principled discussions as compared to the Norwegian documents. This can again be related to differences in the national repertoire, in the sense that the different traditions of writing can be seen as an institutionalization of the historically available repertoire. ${ }^{15}$ And the differences in the national repertoire may be ascribed to broader cultural differences between the nations. The egalitarian ideals of the social democratic political tradition are strong in both countries, but the Swedish culture seems more open to breaking away from these ideals, which makes sense if we look at the different history and nation-building in the countries: whereas Norway was a colony of Denmark and Sweden until 1905, Sweden has been a dominant country in the Nordic region for centuries, basing its nation-building on its great history and traditional nobility (Østerud 1994: 42-3; also Østerud 1987; Rokkan 1987). Although such a tradition is weak compared to continental Europe (Allardt 1992), it is stronger than in Norway. And despite Norway today being a more prosperous country than Sweden (mainly due to oil and gas reserves), and this representing a shift in the power relations between the two, Swedish culture is still more open than Norwegian culture to projects that can be considered formal and elitist - at least by the Norwegian public, which is dominated by a strong sentiment to reject all such projects (see Eriksen (2010) and Witoszek (2010) for a discussion of the shifting power relations between the two neighboring countries). ${ }^{16}$ Let us now move up a rung on the policy ladder and look at how PSB is approached in the white papers on overall cultural policy.

\section{PSB as an Object for Cultural Policy}

To begin with, the Swedish paper - Prop. 1996/1997:3 Kulturpolitik [Cultural Policy] - contains a lot more information on PSB than does the Norwegian paper - St.meld.nr. 48 (2002-2003) Kulturpolitikk fram mot 2014 [Cultural Policy Towards 2014] (they are of approximately the same length). In addition to this being an expression of different traditions for writing policy documents, it may indicate that PSB is given a stronger emphasis from an overall cultural policy perspective in Sweden than in Norway. This can further be related to Swedes putting a stronger emphasis on the idea of PSB in their rhetoric (Larsen 2008; 2010), considering that the papers on overall cultural policy are more fundamental than the papers on PSB; the latter focuses on a concrete object to which cultural policy is applied, while the former focuses on the ideas and values that should guide the more specific areas of cultural policy.

Both the Norwegian (St.meld.nr. 48 (2002-2003)) and the Swedish (Prop. 1996/1997: 3 ) paper on overall cultural policy contain statements of practical cultural politics related to PSB, concerning such issues as maintaining the national culture by airing programs in the national language, airing theater and opera performances from the national stages and mirroring national cultural life, both urban and rural (it is also stated that they should 
mirror international cultural life). ${ }^{17}$ But the Swedish paper differs from the Norwegian in that it also contains a more principled rhetoric about the importance of PSB from a cultural policy perspective. It has its own chapter on mass media, which begins as follows:

The mass media are important for the culture in several respects. The most fundamental is that the freedom of speech, which is a precondition for a free and vibrant cultural life, as for our political democracy, is dependent on the existence of free and independent mass media that can host debates and break opinions. [...] There is a risk that mass media that operate on commercial terms will focus on reaching a broad and general public to such a high degree that diversity will suffer and the content become predictable and trivial. On these grounds, it is urgent that there exist public service companies in radio and television that can ensure diversity and quality without being dependent on a commercial market (Prop. 1996/97:3: 162).

The last two sentences are cited in the latest SOU (2009:16: 204) on overall cultural policy, and followed by this passage:

A strategy for the government's cultural policy is then to come up with a new task for PSB. If it in the past was about covering the complete radio and TV offering, it is now about balancing and being a counterweight to the commercial broadcasters. This is an interesting inversion, as the political debate about commercial broadcasting in the 1980s was largely about the need for an alternative to the, at the time, universal media offering from Sveriges Radio AB.

Such an inversion is also found in the public rhetoric of SVT's CEO, Eva Hamilton, as seen on SVT's early morning show "Gomorron Sverige" (January 25 2007; March 7 2007); she is eager to argue for the importance of SVT as a counterweight to the homogenous commercial offering dominated by the American culture industry and globalized media conglomerates (Larsen 2010). So, both the authors of the Swedish papers and the CEO of SVT are operating within an anti-commercialism discourse, portraying the importance of PSB in relation to the damaging effect that commercial media can have on democracy - "It is important to counter the concentration of power in the media" (Prop. 1996/97:3: 221). Such an opposing rhetoric is not found in the Norwegian documents. There may be several reasons for this: the Norwegians may not feel the need to legitimize the idea of PSB to such a high degree, as NRK has a strong position among the Norwegian public. One of the interviewees at NRK said: "I don't know any [public service broadcaster] that has a similar position among the public [as NRK]". And one at SVT said: "But NRK is the world's leading TV company, if you're talking about market share and the people's support". In 2007, the main PSB channel in Norway, NRK1, had a market share of 38 percent; while the main Swedish PSB channel, SVT1, had a market share of 19 percent (however, the main supplementary channel of SVT has a better market share than the main supplementary channel at NRK: SVT2 had a share of 13 percent, compared to NRK2's 3 percent) (Carlsson 2009: 92). The Norwegian public may then not require such an elaborate argument for the need for a public service broadcaster in a digitized and globalized media sphere. And NRK also (pragmatically) bases its legitimacy on the support of the people, to a larger degree than SVT does (Larsen 2010).

Furthermore, the differences in the national repertoire influence the more abstract rhetoric in Sweden, where the legitimizing rhetoric focuses on both the idea and the 
practical politics of PSB as a tool for cultural policy, while the Norwegian rhetoric is focused on the latter. It is both possible and necessary for Swedes to activate the kind of rhetoric that is used: the public demands an advanced legitimizing rhetoric (Larsen 2008: 329-332) and the national repertoire makes this rhetoric possible. The repertoire seems to have manifested itself in a tradition of writing principled policy documents, at least in the field of cultural policy. In Norway the public does not demand such rhetoric, and the rhetoric that is activated is to a larger degree related to concrete issues and goals, dealing with practical politics, as philosophical and abstract rhetoric are not a constitutive part of the Norwegian national repertoire.

\section{Conclusion}

There are many similarities in the cultural policy related to PSB in Norway and Sweden: the policy documents contain arguments for the key role of PSB for securing an inclusive public sphere and a national culture, and PSB is considered to play an important role in a vibrant democracy. These are arguments that have been activated in the legitimizing rhetoric of PSB throughout its history. The documents in both countries contain practical political obligations, but the Swedish documents argue in addition for the importance of the idea of PSB, basing their argument on an opposition to commercial media, being more in line with the debates going on in other parts of Europe: "The attention focused on the mission of public service broadcasters is greater than ever before, both at the level of European and national regulators, and at the level of the public broadcasting institutions themselves" (Bardoel and d'Haenens 2008: 342-343).

The Norwegian rhetoric is characterized by a slightly more instrumental approach to PSB than what is found in the Swedish rhetoric. Where one in Sweden tends to portray PSB as an end in itself, PSB is rather portrayed as a means toward other ends in Norway. There is also greater emphasis on the technical aspects related to PSB in the current media environment in the Norwegian rhetoric, whereas in Sweden one is more occupied with the media content; the effect of digitalization on the media environment is the main aspect of the "new" that receives the most attention in Norway, while the effect of economic globalization and owner concentration on media content is more in focus in Sweden. An aspect of the "traditional" PSB rhetoric that is still part of the Swedish rhetoric, but absent from the Norwegian, is a PSB institution's role as a presenter of supposedly important information and culture to the audience, which can be related to the Swedish cultural repertoire being more open to the articulation of explicit educational ambitions as well as philosophical rhetoric. Taken together, this serves as an illustration of cultural differences between the two countries; it seems that Swedes are more willing to employ and accept principled rhetoric when discussing cultural policy, whereas Norwegians lean toward more concrete rhetoric.

\section{Acknowledgement}

I am grateful to Anne Krogstad, Per Mangset, Berit Vannebo, Wendy Griswold, Atle Wehn Hegnes, Julia Orupabo, Eli Skogerbø and Nordicom's reviewer for comments on the article. The work was supported by the Norwegian Research Council, through the Leiv Eiriksson Mobility Programme [grant number 192673]. 


\section{Notes}

1. One also approaches media from the perspective of industry policy, consumer policy and competition policy (Syvertsen 2004: 17-22).

2. The license fee accounts for approximately 90 percent of NRK's and SVT's incomes (Lund et al. 2009).

3. For a discussion of Nordic identity, see Allardt (1992).

4. http://www.regjeringen.no/nb/dok/regpubl/stmeld.html?id=1754 (accessed 26 March 2009).

5. Some argue that a SOU is closer to a St.meld. than a Prop., but what makes a Prop. better for comparison with a St.meld. than a SOU is the fact that both a Prop. and a St.meld. have the Government as the addresser.

6. As can be seen, there is quite a span of time between these papers, but they are nevertheless the latest papers on overall cultural policy produced before the papers on PSB in question.

7. For a discussion of the notion of PSB, see Carlsson (1999).

8. Statements related to both aspects are found in the documents of both countries.

9. PSB institutions' role as providers of a set of common references in today's digitalized and globalized media landscape was also stressed as an important feature by the politicians responding to the questionnaire on cultural policy.

10. For a further discussion of how the Habermasian ideal of the public sphere can be related to PSB, see Garnham (1986), Scannel (1989) and Moe (2008).

11. The two languages got their current name from the Storting in 1929.

12. One might expect this to be the other way around, considering that Sweden is a member of the European Union (EU), while Norway is not. But because of the European Economic Area Agreement, Norway has to follow the Law of the European Union. A ritual use of phrases from EU documents in Norwegian legislation and policy documents is also evident when it comes to the adaption of food labeling schemes to Norway (Hegnes 2010).

13. Digital terrestrial television was launched in Sweden in September 1999 and the analogue switch-off took place in October 2007. In Norway it was launched in the fall of 2007 and the switch-off took place at the end of 2009 (Carlsson 2009: 81).

14. "In all developed broadcasting systems the characteristic organisation, and therefore the characteristic experience, is one of sequence of flow. This phenomenon, of planned flow, is then perhaps the defining characteristic of broadcasting, simultaneously as a technology and as a cultural form" (Williams, 1975: 86).

15. The national repertoire may also influence the differences in the usage of the terms "fellow citizen" (which reads medborger in Norwegian [NO] and medborgar in Swedish [SE]) and "enlightenment (of the people)" (folkeopplysning[NO] - see Tøsseland (2004) and Slagstad (2001: 107-110) for a discussion of the term/folkbildning[SE] - see Gustavsson (1991) for a discussion of the term): Where these are not mentioned in either the main or supplementary Norwegian papers on PSB (St.meld.nr.30 (2006-2007); St.meld.nr.6 (2007-2008); St.meld.nr.6 (2008-2009)), the former phrase is mentioned 14 times and the latter 11 times in the Swedish paper on PSB (Prop. 2005/06:112). This can be related to Sweden having an own PSB company, UR, dedicated to the production of educational programs. However, the mentioned differences are also found in the annual reports of the PSB institutions (Larsen 2010). A further illustration is the absence of an article on "enlightenment (of the people)" in the Norwegian version of Wikipedia and its presence in the Swedish version, as of May 3rd 2010. (Enlightenment (of the people) is a direct translation of the Norwegian word folkeopplysning; the "of the people" is intended to distinguish the term enlightenment from its broader notion, related to the age of enlightenment and enlightenment philosophy, and the use of parentheses to not distance it too far from the definition of enlightenment provided by such philosophers - the phrase "popular education" might give more meaning to an English audience). These terms are quite abstract, and they are important within a Habermas inspired democratic approach to PSB (Larsen 2008; Nolan 2006).

16. This difference is also apparent in the actual programs produced by NRK and SVT, especially in debate and culture programs. In the former category, Swedish politicians tend to be given more room for presenting longer arguments, while in the case of Norway the debates are controlled by the journalists to a larger degree (Håkansson 2001; also Allern 2004, for a discussion of the Norwegian case). When it comes to culture, the Norwegian programs tend to have a stronger focus on entertaining the audience than is the case in Sweden, where experts are given more time to discuss and reflect on developments within the cultural field (see Larsen 2006 for an analysis of one of NRK's culture programs).

17. The mean value given to the importance of having a broad offering of culture programs and monitoring national as well as international cultural life is the same in each country when comparing the answers from the cultural politicians. 


\section{References}

Allardt, E. (1992) 'Den nordiska identitetens sociologi', in Karlsson, S. (ed.) En okämd själ - på jakt efter det nordiska. Stockholm: Nordiska rådet.

Allern, S. (2004) 'Fra politikermakt til journalistmakt. Programlederroller i fjernsynsvalgkampen 1961-2001', in Aardal, B., Krogstad, A. and Narud, H.M. (eds.) I valgkampens hete. Oslo: Universitetsforlaget.

Anderson, B. (1991) Imagined Communities. Reflections on the Origin and Spread of Nationalism. (Revised Edition). London: Verso.

Aristotle (1926) The 'Art' of Rhetoric. Great Britain: The Loeb Classical Library.

Bardoel, J. and d'Haenens, L. (2008) 'Reinventing Public Service Broadcasting in Europe: Prospects, Promises and Problems', Media, Culture and Society 30(3): 337-355.

Bengtsson, H. A. (2002) 'Aristokratisk eller folkligt demokrati', in Bengtsson, H. A. (ed.) Folkbildning $i$ vår tid. En antologi om makt og demokrati. Stockholm: Atlas.

Carlsson, U. (ed.) (1999) Public Service-TV. Göteborg: Nordicom.

Carlsson, U. (ed.) (2009) 'Naobolands-TV i en digital tidsalder. Rapport från Nordiskt Kulturforum 29. september 2008', Nordicom Information 2009 (3).

Enli, G.S. (2006) 'Redefining Public Service Broadcasting: Audience Participation and Multi-platform Formats'. Paper presented at the RIPE-conference on Public Service Broadcasting, Amsterdam November 15-17 2006.

Eriksen, T. H. (2010) 'Svorge', in Ruth, A. and Lindahl, B. (eds.) I takt og utakt. Nye historier om Norge og Sverige. Oslo: Schibsteed Forlag.

Esping-Andersen, G. (1990) The Three Worlds of Welfare Capitalism. Princeton, N.J. : Princeton University Press.

Garnham, N. (1986) 'The Media and the Public Sphere', in Golding, P., Murdock, G. and Schlesinger, P. (eds.) Communicating Politics - Mass Communication and the Political Process. Leicester: Leicester University Press.

Garnham, N. (1992) 'The Media and the Public Sphere', in Calhoun, C. (ed.) Habermas and the Public Sphere. Cambridge: The MIT Press.

Garnham, N. (2003) 'A Response to Elizabeth Jacka's "Democracy as Defeat", Television and New Media 4(2): 193-200.

Gundelach, P. (2000) 'Joking Relationships and National Identity in Scandinavia', Acta Sociologica 43(2): 113-122.

Gustavsson, B. (1991) Bildningens väg. Tre bildningsideal i svensk arbetarrörelse 1880-1930. Stockholm: Wahlström \& Widstrand.

Habermas, J. (1989) The Structural Transformation of the Public Sphere: An Inquiry into a Category of Bourgeois Society. Cambridge: Polity Press.

Habermas, J., (1996) Between Facts and Norms: Contributions to a Discourse Theory of Law and Democracy. Cambridge: The MIT Press.

Hallin, D.C. and Mancini, P. (2004) Comparing Media Systems. Three Models of Media and Politics. New York: Cambridge University Press.

Hegnes, A.W. (2010) 'Der Schutz der geographischen Nahrungsmittelherkunft in Norwegen als Übersetzungund Transformationsprozess', in Bauer, S., Bischof, C., Haufe, S.G., Beck, S. and Scholze-Irrlitz, L. (eds.) Essen in Europa. Kulturelle 'Rückstände' in Nahrung und Körper. Bielefeld: Transcript Verlag.

Hesmondhalgh, D. (2005) 'Media and Cultural Policy as Public Policy', International Journal of Cultural Policy 11(1): 95-109.

Håkansson, N. (2001) 'Argumentative and Symbolic Discourse in Nordic Electoral Debate', in Gomard K. and Krogstad, A. (eds.) Instead of the Ideal Debate. Doing Politics and Doing Gender in Nordic Political Campaign Discourse. Århus: Aarhus University Press.

Jacka, E. (2003) '”Democracy as Defeat". The Importance of Arguments for Public Service Broadcasting', Television \& New Media 4(2): 177-91.

Lamont, M. (1992) Money Morals and Manners. Chicago: The University of Chicago Press.

Lamont, M. and Thévenot, L. (2000) 'Introduction: toward a renewed comparative cultural sociology', in Lamont, M. and Thévenot, L. (eds.) Rethinking Comparative Cultural Sociology: Repertoires of Evaluation in France and the United States. Cambridge: Cambridge University Press.

Larsen, H. (2006) Kunstdiskurser $i$ en massemedial offentlighet. En analyse av dominerende forståelser av kunst og kultur i NRK Fjernsynets Store Studio. Thesis (Master). Oslo: University of Oslo.

Larsen, H. (2008) 'I demokratiets tjeneste. Offentlig debatt om allmennkringkasting i Norge og Sverige', Tidsskrift for samfunnsforskning 49(3): 313-342.

Larsen, H. (2010) 'Legitimation Strategies of Public Service Broadcasters: The Divergent Rhetoric in Norway and Sweden', Media, Culture \& Society 32(2): 267-283.

Lund, A.B., Nord, L. and Roppen, J. (2009) Nye utfordringer for gamle medier. Skandinavisk public service $i$ det 21. århundrede. Göteborg: Nordicom. 
Moe, H. (2008) Public Broadcasters, the Internet, and Democracy. Comparing Policy and Exploring Public Service Media Online. Thesis (PhD). Bergen: University of Bergen.

Nolan, D. (2006) 'Media, Citizenship and Governmentality: Defining "The Public” of Public Service Broadcasting', Social Semiotics 16(2): 225-242.

Przeworski, A. and Teune, H. (1970) The Logic of Comparative Social Inquiry. New York: John Wiley \& Sons. Reith, J. (1924) Broadcast over Britain. London: Hodder \& Stoughton.

Rokkan, S. (1987) Stat, nasjon, klasse. Oslo: Universitetsforlaget.

Røyseng, S. (2008) 'The Ritual Logic of Cultural Policy', Paper presented at the Fifth International Conference on Cultural Policy Research, Istanbul August 20-24.

Scannell, P. (1989) 'Public Service Broadcasting and Modern Public Life', Media, Culture \& Society 11(2): 135-66.

Sejersted, F. (2005) Sosialdemokratites tidsalder. Norge og Sverige i det 20. Arhundre. Oslo: Pax.

Slagstad, R. (2001) De nasjonale strateger. Oslo: Pax.

Storsul, T. and Sundet, V. S. (2006) 'Digital Terrestrial Television in Scandinavia', in Colombo, F. and Vittadini, N. (eds.) Digitising TV. Theoretical Issues and Comparative Studies across Europe. Milano: Vita e Pensiero.

Sunstein, C. R. (2007) Republic.com 2.0. Princeton: Princeton University Press.

Syvertsen, T. (2004) Mediemangfold. Styring av mediene i et globalisert marked. Kristiansand: IJ-forlaget.

Tøsse, S. (2004) Frå folkeopplysning til vaksenopplaering. Thesis (Dr.philos). Trondheim: Norwegian University of Science and Technology.

Vestheim, G. (1995) Kulturpolitikk i det moderne Noreg. Oslo: Det Norske Samlaget.

Williams, R. (1975) Television. Technology and Cultural Form. New York: Schocken Books.

Witoszek, N. (2010) 'Kalmarunionen da capo?', in Ruth, A. and Lindahl, B. (eds.) I takt og utakt. Nye historier om Norge og Sverige. Oslo: Schibsteed Forlag.

Østerud, Ø. (1987) 'Nationalism och modernitet. Ett skandinaviskt perspektiv', in Therborn, G. (ed.) Lycksalighetens halvö. Den svenske välfärdsmodellen och Europa. Stockholm: FRN-Framtidsstudier.

Østerud, Ø. (1994) Hva er nasjonalisme? Oslo: Universitetsforlaget.

\section{Policy Documents}

EU (1997) Protocol on the system of public broadcasting in the Member States. Official Journal C 340, 10/11/1997 P. 0109.

LOV-1992-12-04-127 Lov om kringkasting.

Regeringens proposition 1996/97:3 Kulturpolitik.

Regeringens proposition 2000/01:94 Radio ochTV $i$ allmänhetens tjänst 2002-2005.

Regeringens proposition 2005/06:112 Viktigare än någonsin! Radio och TV i allmänhetens tjänst 2007-2012. SOU 2009: 16 Betänkande av Kulturutredningen.

St.meld. nr. 57 (2000-2001) I ytringsfrihetens tjeneste. Mål og virkemidler i mediepolitikken.

St.meld. nr. 48 (2002-2003) Kulturpolitikk fram mot 2014.

St.meld.nr. 30 (2006-2007) Kringkasting $i$ en digital fremtid.

St.meld.nr. 6 (2007-2008) NRK-plakaten. 'Noe for alle. Alltid'.

St.meld.nr. 6 (2008-2009) NRK-plakaten - NRKs samfunnsoppdrag.

\section{Other Data Sources}

Bakke, Hallvard. Chairman of NRK 2006-2010, and Norwegian Minister of Culture and Science 1986-1989, representing the Norwegian Labour Party. Interviewed on March 112008.

Gomorron Sverige [Good Morning Sweden]. Early morning TV show. Interview with CEO of SVT, Eva Hamilton, January 25 and March 72007.

HÅKON LARSEN, Ph.D., Researcher, Department of Media and Communication, University of Oslo, hakon.larsen@media.uio.no 